DOI: 10.32844/2222-5374-2020-104-2.28

УДК: 342.9

Мамульчик А. М., здобувач Державного науково-дослідного інституту МВС Украӥни

\title{
ПРИНЦИП НАЙКРАЩОГО ЗАБЕЗПЕЧЕННЯ ПРАВ ДИТИНИ ЯК ОСНОВНИЙ ПРИНЦИП АДМІНІСТРАТИВНО-ПРАВОВОГО ЗАБЕЗПЕЧЕННЯ СТАТУСУ ДИТИНИ, РОЗЛУЧЕНОЇ З СІМ'ЄЮ
}

Актуальність статті полягає в тому, що міграція населення є однією з найважливіших проблем сучасності. За даними Організації Об'єднаної Нації, кількість мігрантів у сучасному світі досягає 80 млн. осіб., при цьому третину цього потоку складають діти. Не оминула ия проблема і Україну. Щорічно в Україну прибувають сотні дітей у відсутності супроводу з боку дорослих (членів родини або визначених законом/звичаєм осіб), які несуть відповідальність за таку особу), які у міжнародному та національному праві визнаються дітьми без супроводу (дітьми, розлученими з сім'єю). У зв'язку з цим особливої актуальності набуває аналіз змісту та елементів адміністративно-правового забезпечення надання таким особам спеціального статусу (дитини, розлученої з сім'єю, біженця чи особи, що потребує додаткового захисту), особливо - принципів такого забезпечення. З'ясовано, що принципи адміністративно-правового забезпечення надання статусу дитини, розлученої з сім'єю, являють собою основні, вихідні, загальні, об'єктивно зумовлені засади, що слугують орієнтирами при формуванні нормативно-правового регулювання надання особі особливого статусу (дитини, розлученої з сім'єю, біженця, особи, що потребує додаткового захисту), пред'являються до діяльності суб'єктів публічного адміністрування, що приймають рішення про надання особі такого статусу, організації та функціонування механізму адміністративно-правового забезпечення надання вищевказаного статусу. В національному законодавстві принципів, які б встановлювалися до адміністративно-правового забезпечення статусу дитини, розлученої з сім'єю, або навіть до правового статусу такої дитини, не закріплюється. Відсутність нормативного закріплення зазначених принципів обумовлюється розвитком національного законодавства у цій сфері, порівняно недавньою ратифікацією Украӥни ряду міжнародних документів у сфері захисту біженців та дітей, відвертим нехтуванням 3 боку уряду до подальшого удосконалення національного законодавства у сфері забезпечення прав дітей - шукачів притулку, в тому числі права на отримання ними статусу дитини, розлученої з сім'єю.

Ключові слова: адміністративно-правове забезпечення, суб'єкти господарювання, міжнародне законодавство, інтереси дитини.

Актуальність теми. Міграція населення є однією з найважливіших проблем сучасності. За даними Організації Об’єднаної Нації, кількість мігрантів у сучасному світі досягає 80 млн. осіб., при цьому третину цього 
потоку складають діти. За даними Департаменту з економічних та соціальних питань Секретаріату ООН, Дитячого фонду ООН (ЮНICЕФ), у світі нараховується 31 млн. дітей, що проживають поза країною свого народження, з яких більше 11 млн. дітей біженців та дітей, що шукають притулку, та 17 млн. дітей, переміщених в межах території своїх держав [2].

Не оминула ця проблема і Україну. Щорічно в Україну прибувають сотні дітей у відсутності супроводу з боку дорослих (членів родини або визначених законом/звичаєм осіб), які несуть відповідальність за таку особу), які у міжнародному та національному праві визнаються дітьми без супроводу (дітьми, розлученими з сім'єю). У зв'язку з цим особливої актуальності набуває аналіз змісту та елементів адміністративно-правового забезпечення надання таким особам спеціального статусу (дитини, розлученої з сім'єю, біженця чи особи, що потребує додаткового захисту), особливо - принципів такого забезпечення.

Стан дослідження. Принципи адміністративно-правового забезпечення як елемент змісту такого забезпечення досліджувався у роботах Б. Бойка, А. Замриги, С. Діденка, Л. Сопільника, В. Горохольского, Є. Сердюка, В. Трофімцова, Клименка, Н. Шевчука та інших.

Виклад основного матеріалу. Науковці підходять до визначення принципів адміністративно-правового забезпечення, спираючись на загальне визначення принципів права (як вихідних, визначальних ідей, положень, установок, які становлять моральну та організаційну основу виникнення, розвитку і функціонування права) [9] та принципів адміністративного права (які визначаються як орієнтири та пріоритетні засади правового регулювання у сфері державного управління, загальні засади визначення правових рамок компетенції органів публічної адміністрації, що визначають і конкретизують цілепокладання, створюють умови для реалізації прав та свобод людини і громадянина, інших суб'єктів в означеній сфері, взаємопов'язані з гарантіями забезпечення реалізації означених прав та засобами адміністративного примусу) [4].

Серед наукових робіт, присвячених дослідженню цього питання, особливої уваги привертає дослідження Ю. Лавренюка, в якому він вдається до аналізу принципів адміністративно-правового забезпечення економічних інтересів України. Автор зазначає, що принципи адміністративно-правового забезпечення $\epsilon$ новелою у доктрині адміністративного права, яка має наступні особливості: 1) попри наявність загального призначення, принципи відповідного адміністративно-правового забезпечення мають загальну, вищу «надціль» - забезпечення прав і свобод людини, що означає сприйняття діяльності держави у цій сфері виключно як комплексної гарантії таких прав і свобод; 2) зазначені принципи повинні мати нормативний характер, що означає відображення їх у нормативних документах; 3) опрацювання подальшого розвитку принципів адміністративно-правового забезпечення передбачає врахування надбань як адміністративно-правової доктрини, так доктрини державного управління [16]. Сам науковець принципи адміністративно-правового забезпечення економічних інтересів України визначає як нормативно закріплені визначальні засади адміністративно-правового регулювання, що здійснюється із зазначеною метою [16]. 
Пропонують авторське визначення принципів адміністративно-правового забезпечення і інші науковці. Так, С. Діденко принципи адміністративно-правового забезпечення обігу та застосування зброї визначає як основні вихідні, об'єктивно зумовлені засади, на яких базується діяльність суб'єктів публічного адміністрування щодо забезпечення обігу та застосування зброї з метою забезпечення прав громадян на самозахист, оборони України від зовнішньої агресії, нормального функціонування держави та громадянського суспільства [7]. В. Трофімцов до принципів адміністративно-правового забезпечення протидії тероризму підходить як до безпосередньо чи опосередковано відображених у нормах позитивного права, зумовлених особливостями об'єктивного розвитку суспільного життя та заснованих на них, найбільш загальних, базисних, імперативних вимог, що пред'являються до організації та функціонування механізму адміністративно-правової протидії тероризму, відповідно до яких повинні будувати та реалізовувати свою поведінку суб’єкти цієї протидії [25]. А. Замрига під принципами адміністративно-правового забезпечення господарської діяльності в Україні розуміє сукупність нормативно зафіксованих рамок, об'єктивованих у вигляді приписів, указівок, настанов та гарантій, що визначають спрямування простору впливу регулювальних адміністративних норм на сферу суспільних відносин, що виникають між державою та суб'єктами господарювання, а також процедурах їх взаємодії та загального функціонування економічного ринку країни [10]. Є. Сердюк до принципів адміністративно-правового забезпечення виборчих прав громадян підходить як до основних вихідних, об'єктивно зумовлених засад, на яких базується діяльність суб'єктів адміністративного права щодо забезпечення виборчих прав громадян України, нормальне функціонування держави та громадянського суспільства в цілому [24]. Виходячи з визначень, запропонованих науковцями, можна констатувати, що принципами адміністративно-правового забезпечення $\epsilon$ основні, вихідні, загальні, об'єктивно зумовлені засади, що слугують орієнтирами при формуванні нормативно-правового регулювання, пред'являються до діяльності суб'єктів публічного адміністрування, організації та функціонування механізму адміністративно-правового забезпечення у певній сфері, тобто визначають напрями формування змісту адміністративно-правового регулювання.

Таким чином, принципи адміністративно-правового забезпечення надання статусу дитини, розлученої з сім'єю, являють собою основні, вихідні, загальні, об'єктивно зумовлені засади, що слугують орієнтирами при формуванні нормативно-правового регулювання надання особі особливого статусу (дитини, розлученої з сім'єю, біженця, особи, що потребує додаткового захисту), пред'являються до діяльності суб'єктів публічного адміністрування, що приймають рішення про надання особі такого статусу, організації та функціонування механізму адміністративно-правового забезпечення надання вищевказаного статусу.

В національному законодавстві принципів, які б встановлювалися до адміністративно-правового забезпечення статусу дитини, розлученої з сім'єю, або навіть до правового статусу такої дитини, не закріплюється. Відсутність нормативного закріплення зазначених принципів обумовлю- 
ється розвитком національного законодавства у цій сфері, порівняно недавньою ратифікацією України ряду міжнародних документів у сфері захисту біженців та дітей, відвертим нехтуванням з боку уряду до подальшого удосконалення національного законодавства у сфері забезпечення прав дітей - шукачів притулку, в тому числі права на отримання ними статусу дитини, розлученої з сім'єю.

Водночас, в міжнародній сфері принципи забезпечення прав дітей, в тому числі, прав дітей - шукачів притулку на отримання спеціального статусу дитини без супроводу закріплюються у ряді нормативних актів Загальній декларації прав людини, Міжнародному пакті про цивільні та політичні права, Декларації прав дитини ООН від 20.11.1959, Конвенції про захист прав дітей, Конвенції про ліквідацію всіх форм дискримінації відносно жінок, Конвенції про захист дітей та співробітництво в галузі міжнародного усиновлення 1993 р., Конвенції про юрисдикцію, право, що застосовується, визнання, виконання та співробітництво щодо батьківської відповідальності та заходів захисту дітей, Європейській конвенції про здійснення прав дітей, Керівних принципах Комітету міністрів Ради Європи щодо правосуддя, дружнього до дітей від 07.11.2010, Декларації про соціальні та правові принципи, що стосуються захисту і благополуччя дитини, особливо при переданні дітей на виховання і при їх усиновленні на національному та міжнародному рівнях 1986 р. та інших.

Зазначені принципи узагальнені та викладені у Кодексі практики 3 захисту дітей-мігрантів і осіб, що шукають притулку, підготовленого в рамках проекту регіонального офісу УВКБ ООН і розробленого для служб систем в'їзду та міграційного контролю. Згідно зі ст. 1.3 цього Кодексу, до принципів діяльності для спеціальних служб, на які покладається обов'язок вирішення питання про надання дитині без супроводу статусу дитини, розлученої з сім'єю, відносяться: 1) принцип найкращого забезпечення інтересів дитини; 2) принцип недискримінації; 3) принцип забезпечення права на життя, виживання та розвиток дитини; 4) принцип забезпечення права дитини на вислухування і прийняття до уваги їх думки та побажання при прийнятті рішень, що впливають на їх життя; 5) діти - шукачі притулку, знаходяться у більш вразливому становищі, ніж дорослі, а отже вимагають більш уважного відношення.

Серед означених принципів особливої уваги привертає принцип найкращого забезпечення інтересів дитини, тому метою нашої статті стане дослідження сутності зазначеного принципу як загального принципу забезпечення інтересів дитини, спираючись на яке, буде визначено сутність цього принципу як принципу адміністративно-правового забезпечення надання статусу дитини, розлученої з сім'ю.

Принцип найкращого забезпечення інтересів дитини $є$ фундаментальним, всезагальним та комплексним, який покладається в основу забезпечення всіх прав та інтересів дитини, в тому числі її права на набуття спеціального статусу дитини без супроводу. У Зауваженнях загального порядку № 12, розроблених Комітетом ООН з прав дитини, принцип найкращого забезпечення інтересів дитини займає особливе місце, оскільки всі останні принципи повинні реалізовуватися з урахуванням принципу найкращого забезпечення інтересів дитини [14]. 
Вищевказаний принцип закріплюється, насамперед, у ст. 3 Конвенції про захист прав дитини, в ч. 1 якої зазначається, що в усіх діях щодо дітей, незалежно від того, здійснюються вони державними чи приватними установами, що займаються питаннями соціального забезпечення, судами, адміністративними чи законодавчими органами, першочергова увага приділяється якнайкращому забезпеченню інтересів дитини, а в ч. 3 визначається, що держави-учасниці зобов'язуються забезпечити дитині такий захист і піклування, які необхідні для їі благополуччя, беручи до уваги права й обов'язки її батьків, опікунів чи інших осіб, які відповідають за неї за законом, і з цією метою вживають всіх відповідних законодавчих і адміністративних заходів [13]. Виходячи з цього пункту Конвенції, у дітей з'являється право те, щоб його найкращі інтереси оцінювалися і приймалися до уваги в першу чергу при прийнятті відносно нього рішень на державному чи приватному рівнях. Один з авторів Конвенції про захист прав дитини Дж. Ван Бюрен писала, що «...поняття «найкращих інтересів дитини» надає особам, що приймають рішення і визначають політику, повноваження замінити рішення будь-якого з батьків дитини власними, за умов, що вони грунтуються на міркуваннях, пов'язаних з найкращими інтересами дитини; через це Конвенція про права дитини кидає виклик уявленням, згідно яким сімейне життя завжди відповідає найкращим інтересам дітей, а батьки завжди здатні вирішити, що краще для їх дітей» [6]. Дитина з залежного об'єкту «батьківської влади» стала незалежним суб'єктом права.

Зустрічається посилання на принцип забезпечення найкращих інтересів дитини і в інших міжнародних нормативних актах. Так, у ст. 6 Європейської конвенції про здійснення прав дітей передбачається, що порядок прийняття рішення про дитину повинен враховувати принцип найкращих інтересів дитини і перед прийняттям рішення судовий орган: а) визначає, чи має він достатньо інформації для прийняття рішення в найвищих інтересах дитини, і в разі необхідності одержує додаткову інформацію, зокрема від суб'єктів батьківської відповідальності; б) якщо внутрішнім законодавством дитина визнається такою, що має достатній рівень розуміння: упевнюється в тому, що дитина отримала всю відповідну інформацію; у відповідних випадках консультує особисто дитину (в разі необхідності - приватно) сам або через інших осіб чи інші органи у зрозумілий дитині спосіб, якщо це явно не суперечить найвищим інтересам дитини; надає можливість дитині висловлювати ї̈ думки; в) приділяє належну увагу думкам, висловленим дитиною [8]. У Керівних принципах Комітету міністрів Ради Європи щодо правосуддя, дружнього до дітей від 07.11.2010, які є інструментом адаптації державами-учасницями їхніх судових і позасудових система до специфічних прав, інтересів та потреб дітей, закріплюється, що держави-члени повинні гарантувати ефективне здійснення прав дітей, щоб їх найкращі інтереси мали першочергову увагу в усьому, що їх стосується [12].

3 огляду на всезагальність та комплексність принципу найкращого забезпечення інтересів дитини, його використання у різних міжнародних документах, Комітет з прав дитини ООН розробив Зауваження загального порядку № 14 (2013) «Про право дитини на приділення першочергової уваги якнайкращому забезпеченню її інтересів», в якому безпосередньо 
зазначається, що інтересам дитини не просто приділяється першочергова увага, а вони враховуються в першочерговому порядку і при оцінці найкращих інтересів дитини необхідно дотримуватися балансу всіх елементів, необхідних для прийняття рішення в конкретній ситуації для конкретної дитини або групи дітей; держава повинна поважати, захищати та реалізовувати всі права дитини та враховувати короткострокові, середньострокові та довгострокові наслідки дій, що стосуються розвитку дитини з плином часу [1].

Спираючись на аналіз міжнародних нормативних актів, в яких закріплюється і визначається принцип забезпечення найкращих інтересів дитини, М. Менжул вірно зазначає, що на міжнародному рівні принципу найкращого забезпечення прав дитини надано надзвичайно широку сферу дії [18]. Дійсно, практичне втілення зазначений принцип як у законодавстві держав, що підписали Конвенцію про права дитини (принцип найкращого забезпечення прав дитини закріплений на конституційному рівні у всіх країнах - членах Ради Європи, крім Великобританії, Норвегії та Франції), так і у практиці Європейського суду з прав людини (надалі - ЄСПЛ), де став визначальним у прийнятті рішень по справах «Olsson v. Sweden (no. 1)» від 25.03.1988, «Olsson v. Sweden (no. 2)» від 30.10.1992, «Haase v. Germany» від 08.04.2004, «Pini and Others v. Romania» від 22.06.2004, «Курочкін проти України» від 20.05.2010, «Хант проти України» від 7.12.2006 тощо.

Виходячи 3 аналізу міжнародних нормативних актів та практики ЄСПЛ, в яких визначається сутність принципу найкращого забезпечення інтересів дитини, зазначимо, що в його основі полягає концепція прав дитини, згідно з якою дитина $є$ незалежною людиною, що має свої потреби, інтереси і права, яка взмозі розглядатися не лише як об'єкт піклування, але й як суб'єкт, чиїх прав та інтересів необхідно дотримуватися, а отже коли батьки не справляються зі своїми обов'язками перед дитиною такою мірою, що це може згубно відбитися на їх безпеці чи благополуччі, держава за допомогою відповідних заходів повинна замінити батьків з тим, щоб прийняти рішення відносно дитини, яке б створило для неї найкращі умови для проживання та розвитку з урахуванням короткострокових, середньострокових та довгострокових наслідків прийняття такого рішення для дитини з плином часу [17].

Незважаючи на вагому роль принципу найкращого забезпечення прав дитини і його вагому роль в міжнародному законодавстві, визначення його сутності не міститься в жодному міжнародному документі. Голова Комітету ООН з прав дитини Дж. Зерматтен вказує, що принцип якнайкращого забезпечення інтересів дитини був лише нещодавно представлений правовим системам, і хоча $є$ потенційно багатофункціональним, проте маловивченим з позицій порівняльного правознавства [3].

В правовій доктрині існують різноманітні тлумачення принципу найкращих інтересів дитини. Так, Ж. Петрочко вважає, що принцип забезпечення найкращих інтересів дитини - це задоволення індивідуальних потреб дитини відповідно до її віку, статі, стану здоров'я, особливостей розвитку, життєвого досвіду, родинної, культурної та етнічної належності з урахуванням думки дитини [22], а М. Менжул наполягає, що принцип найкращих інтересів дитини означає пріоритетне врахування батьками, 
законними представниками дитини, органами влади, судом та іншими особами інтересів дитини під час вчинення дій або прийняття ними рішень, які спрямовані на задоволення будь-яких індивідуальних потреб дитини відповідно до її віку, статі, стану здоров'я та особливостей розвитку [18]. А. Ольхова вважає, що найкращі інтереси дитини полягають у формуванні дитини як активного учасника свого життя шляхом володіння нею правом на найкраще забезпечення своїх інтересів [21]. Аналіз інших теоретичних робіт, спрямованих на дослідження принципу забезпечення найкращих інтересів дитини, переконує, що вони переважно грунтуються на визначенні науковцями поняття «найкращі інтереси дитини», забезпечення яких, на їх думку, і визначає сутність вищевказаного принципу. Так, М. Самофал пропонує визначити найкращі інтереси дитини як дискреційний правовий критерій визначення потреб дитини, задоволення яких допоможе забезпечити її здоровий і нормальний фізичний, розумовий, моральний, духовний і соціальний розвиток в умовах свободи і достоїнства [23]. I. Демченко наполягає, що найкращі інтереси дитини - це певний підхід, відповідно до якого благополуччя дитини, її інтереси стоять вище прав інших заінтересованих осіб [5]. О. Ільїна вбачає інтереси дитини у створенні умов, необхідних для його утримання та сприяння його розвитку [11]. Подібну позицію розділяє О. Нечаєва, яка зазначає, що саме розвиток слугує основним критерієм при визначенні інтересів дитини, слугує першим шагом до визначення його дійних інтересів як особистості, що розвивається [20]. О. Кравчук підходить до інтересів дитини як до потреб дитини в благах, що забезпечують його гармонічний розвиток як особистості або прагнення до ïx досягнення, що охороняються законом [15]. О. Миролюбова доповнює попереднього автора, зазначаючи, що потреба дитини в благах, що забезпечують його гармонічний розвиток як особистості або прагнення до їх досягнення є регулятором діяльності дитини, його батьків, законних представників та інших суб'єктів, уповноважених державних органів [19].

Виходячи з доктринальних досліджень принципу найкращого забезпечення прав дитини, зазначимо, що до елементів змісту цього принципу можна віднести те, що він передбачає пріоритетне врахування особами, які несуть відповідальність за дитину (батьками, законними представниками дитини, органами влади, судом та іншими особами) під час вчинення дій або прийняття ними рішень, інтересів дитини, тобто створенні найкращих умов, необхідних для її утримання, забезпеченні потреб у благах, що сприятимуть гармонічному, здоровому і нормальному розвитку такої дитини як особистості у фізичний, розумовий, моральний, духовний і соціальний сферах.

Враховуючи визначення нами сутності принципу найкращого забезпечення інтересів дитини, здійснене на підставі аналізу міжнародного законодавства та доктринальних досліджень, вважаємо, що сутність вищевказаного принципу можна сформулювати таким чином: він передбачає пріоритетне врахування особами, які несуть відповідальність за дитину, під час вчинення дій або прийняття ними рішень відносно неї, інтересів дитини, тобто дії, що вчинюється чи рішення, що приймається відносно дитини повинні забезпечити для неї найкращі умови для утримання та гармонічного, здорового і нормальному розвитку з урахуванням коротко- 
строкових, середньострокових та довгострокових наслідків прийняття такої/го дії/рішення для дитини з плином часу.

Виходячи зі змісту ст. 3 Конвенції про права дитини, де зазначається, що принцип найкращого забезпечення інтересів дитини є першочерговим в діяльності установ, що приймають рішення у всіх справах щодо дітей [13], констатуємо, що принцип найкращого забезпечення інтересів дитини повинен бути основним принципом адміністративно-правового забезпечення надання статусу дитини, розлученої з сім'єю (біженця чи особи, що потребує додаткового захисту), сутність якого у цьому контексті полягатиме в тому, що при розробленні нормативно-правового регулювання надання дитині без супроводу спеціального статусу (дитини, розлученої з сім'єю, біженця чи особи, що потребує додаткового захисту) в країні та адміністративних правовідносин у цій сфері, а також при прийнятті рішень про надання такого статусу суб'єктами публічного адміністрування по кожній індивідуальній справі окремо необхідно забезпечити пріоритетне врахування інтересів дитини з метою забезпечення для неї найкращих умови для утримання та гармонічного, здорового і нормального розвитку з урахуванням короткострокових, середньострокових та довгострокових наслідків прийняття такої/го дії/рішення для дитини 3 плином часу.

\section{СПИСОК ВИКОРИСТАНИХ ДЖЕРЕЛ}

1. Committee on the Rights of the Child, General Comment No. 14 (2013). URL: http://www2.ohchr.org/English/bodies/crc/docs/GC/CRC_C_GC_14_ENG. pdf

2. Uprooted: The growing crisis for refugee and migrant children: report. United Nations Children's Fund (UNICEF). 2016. URL: https://www.unicef.org/ videoaudio/PDFs/Uprooted.pdf.

3. Zermatten J. The Best Interests of the Child. Literal Analysis. Function and Implementation. Working Report, 2010. P. 3 [Електронний ресурс]. - Режим доступу: http://www.childsrights.org/html/documents/wr/wr_best_interest_child09.pdf

4. Адміністративне право України. Загальна частина. Академічний курс: підручник / за заг. ред. О.М. Бандурки. Х.: Золота миля, 2011. 584 с.

5. Демченко I.C. Найкращі інтереси дитини у сфері охороні здоров'я: український підхід. Часопис Київського університету права. 2016. № 4. С. 170-176.

6. Джеральдина Ван Бюрен «Международное право о правах ребенка». Международное право. 1998. С.46-47.

7. Діденко С.В. Адміністративно-правове забезпечення обігу та застосування зброї в Україні. дис... д-ра юрид. наук, Київ, 2016. С. 443

8. Європейська конвенція про здійснення прав дітей від 25.01.1996. URL: https://zakon.rada.gov.ua/laws/ show/994_135

9. Зайчук О.В. Принципи права в контексті розвитку загальної теорії держави і права. Альманах права. 2012. Вип. 3. С. 22-28.

10. Замрига Г. Система принципів адміністративно-правового забезпечення господарської діяльності в україні. http://pgp-journal.kiev.ua/ archive/2019/7/15.pdf 
11. Ильина О. Ю. Понятие и иерархия интересов в семье и семейных правоотношениях. Проблема гармонизации частных и публичных интересов в семейном праве Российской Федерации. М.: Юнити, 2015. С. 52-56

12. Керівних принципах Комітету міністрів Ради Європи щодо правосуддя, дружнього до дітей від 7 листопада 2010 року

13. Ковенція про захист прав дитини від 20.11.1989. URL. https://zakon.rada.gov.ua/laws/show/995_021\#Text

14. Комитет ООН по правам ребенка. Замечание общего порядка № 12 (пункты 70-74) [Электронный ресурс]. Режим доступа: http:// tbinternet.ohchr.org/_layouts/treatybodyexternal/TBSearch.aspx?Lang=ru\&TreatyID=5\&DocTypeID=11

15. Кравчук Н. В. «Наилучшие интересы ребенка»: содержание понятия и его место в семейном законодательстве России. Актуальные проблемы российского права. Москва, 2017. № 5 (78). С. 97-103

16. Лавренюк Ю. Принципи адміністративно-правового забезпечення економічних інтересів україни: сутність та ознаки. https://cyberleninka. $\mathrm{ru} /$ article/n/printsipi-administrativno-pravovogo-zabezpechennyaekonomichnih-interesiv-ukrayini-sutnist-ta-oznaki

17. Мамульчик А.М. Принцип найкращого забезпечення прав дитини (огляд міжнародного законодавства). Право як ефективний суспільний регулятор: Матеріали міжнародної науково-практичної конференції, м. Львів, 15-16 лютого 2019 р. Львів: Західноукраїнська організація «Центр правничих ініціатив», 2019. С. 66-69.

18. Менжул М. Зміст принципу найкращих інтересів дитини та його практичне застосування. Науковий вісник Ужгородського національного університету, 2019. Серія ПРАВО. Випуск 56. Том 1. Вип. 87-92.

19. Миролюбова О. Г. О семейно-правовом понятии «интересы ребенка». Вестник ЯрГУ. Сер.: Гуманитарные науки. 2012. № 4/1. С. 56-58

20. Нечаева А. М. Защита интересов ребенка в многодетной семье. $3 a-$ коны России. Опыт, анализ, практика. 2012. № 6. С. 59-67.

21. Ольхова А. Принцип якнайкращого забезпечення інтересів дитини у міжнародному гуманітарному праві. Часопис Київського університету права. 2013. № 1. С. 348-352

22. Петрочко Ж.В. Найкращі інтереси дитини: сутність ішляхи забезпечення. Наукові записки НДУ ім. М. Гоголя. Психолого-педагогічні науки. 2014. № 3. С. 70-74

23. Самофал М. М. Особливості процесу прийняття медичних рішень щодо дитини: пропозиції до законодавства. Науковий вісник Ужгородського національного університету. Ужгород: Гельветика, 2013. Вип. 21. Т. 1. № Ч. 2. С. 266-268.

24. Сердюк Є.В. Принципи адміністративно-правового забезпечення виборчих прав громадян України. 2014. № 2. С. 72-78

25. Трофімцов В.А. Принципи адміністративно-правового забезпечення протидії тероризму. Науковий вісник Академії муніципального управління. Серія: Право. 2015. Вип. 1 (1). С. 232-240. 


\section{A. Mamulchyk}

\section{THE PRINCIPLE OF THE BEST PROTECTION OF THE RIGHTS OF THE CHILD AS THE BASIC PRINCIPLE OF ADMINISTRATIVE AND LEGAL ENSURING THE STATUS OF A CHILD SEPARATED FROM A FAMILY}

The relevance of the article is that migration is one of the most important problems of our time. According to the United Nations, the number of migrants in the modern world reaches 80 million, with a third of this flow being children. This problem has not escaped Ukraine either. Hundreds of unaccompanied children arrive in Ukraine every year in the absence of adults (family members or persons designated by law / custom) who are responsible for such a person, who are recognized as unaccompanied children in international and national law (children separated from their families). In this regard, the analysis of the content and elements of administrative and legal support for granting such persons a special status (a child separated from the family, a refugee or a person in need of additional protection), especially the principles of such provision, becomes especially relevant. It was found that the principles of administrative and legal support for granting the status of a child separated from the family are the basic, initial, general, objectively determined principles that serve as guidelines in the formation of legal regulation of granting a person special status (child, divorced from the family, refugee, person in need of additional protection), are brought to the activities of public administration entities that decide to grant the person such status, organization and functioning of the mechanism of administrative and legal support for the above status. National law does not enshrine the principles governing the administrative and legal maintenance of the status of a child separated from the family, or even the legal status of such a child. The lack of normative enshrinement of these principles is due to the development of national legislation in this area, the relatively recent ratification of a number of international instruments in the field of refugee and child protection, the government's outright disregard for further improvement of national legislation on asylum seekers' rights. to obtain the status of a child divorced from the family.

Keywords: administrative and legal support, business entities, international law, interests of the child. 